\title{
KINETIKA MIKRO DEKOMPOSISI METANA MENJADI KARBON NANOTUBE PADA PERMUKAAN KATALIS Ni-Cu-Al
}

\author{
Praswasti Pembangun Dyah Kencana Wulan, Widodo Wahyu Purwanto*), \\ dan Yuswan Muharam
}

Departemen Teknik Kimia, Fakultas Teknik Universitas Indonesia

Kampus Baru UI-Depok, 16424, Telp. 021-7863516; Faks. 021-7863515

${ }^{*}$ Penulis korespondensi: widodo@che.ui.ac.id

\begin{abstract}
MICRO KINETICS OF DECOMPOSITION OF METHANE TO CARBON NANOTUBES OVER NI-CU-AL CATALYST. The main focus of this research was to obtain micro kinetics decomposition of methane producing carbon nanotube on the surface of the Ni-Cu-Al catalyst. Experimental kinetics data collected at a temperature range of $650-750^{\circ} \mathrm{C}$ and pressure of one atmosphere. The preliminary test was conducted to obtain the kinetics are not influenced by external and internal diffusion limitations as well as inter-phase transfer. Kinetics data were tested by micro kinetic model derived from the catalyst surface reaction mechanism. The most appropriate kinetic model becomes the rate-limiting step of methane decomposition reaction. Results of preliminary experiment showed that the kinetics of the external diffusion effect is negligible at flow rates above $150 \mathrm{~mL} / \mathrm{min}$. Internal diffusion can be ignored with a catalyst under $0.25 \mathrm{~mm}$ in diameter with a weight of 0.04 grams of catalyst and contact time $2.5 \times 10^{-4}$. Rate equation analysis shows that the ratelimiting step is the adsorption which indicates that intermediate consumption $\left(\mathrm{CH}_{4} \mathrm{I}+\mathrm{I} \Leftrightarrow \mathrm{CH}_{3} \mathrm{I}+\right.$ $\mathrm{HI}$ ) is faster than the formation of intermediate (adsorption of methane, $\mathrm{CH}_{4}+\mathrm{I} \Leftrightarrow \mathrm{CH}_{4} \mathrm{I}$ ). The activation energy obtained for $34.628 \mathrm{~kJ} / \mathrm{mol}$ and pre-exponential factor of $6.583 \times 10^{6}$.
\end{abstract}

Keywords: carbon nanotube; methane decomposition reaction; micro kinetic model; $\mathrm{Ni}-\mathrm{Cu}-\mathrm{Al}$ catalyst; adsorption

\begin{abstract}
Abstrak
Fokus utama penelitian ini adalah memperoleh kinetika mikro dekomposisi metana yang menghasilkan Carbon Nanotube pada permukaan katalis Ni-Cu-Al. Data kinetika eksperimen diambil pada rentang temperatur $650-750^{\circ} \mathrm{C}$ dan tekanan 1 atmosfer. Percobaan pendahuluan dilakukan untuk memperoleh daerah kinetika yang tidak dipengaruhi oleh limitasi difusi eksternal dan internal serta perpindahan antar fasa. Data kinetika diuji dengan model kinetika mikro yang diturunkan dari mekanisme reaksi permukaan katalis. Model kinetika yang paling sesuai menjadi tahap pembatas laju reaksi dekomposisi metana. Hasil percobaan pendahuluan kinetika menunjukkan bahwa pengaruh difusi eksternal dapat diabaikan pada laju alir di atas $150 \mathrm{~mL} / \mathrm{menit}$. Difusi internal dapat diabaikan dengan menggunakan katalis berdiameter di bawah 0,25 mm dengan berat katalis 0,04 gram pada

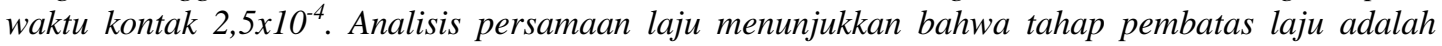
tahap adsorpsi yang menunjukkan bahwa konsumsi intermediate $\left(\mathrm{CH}_{4} \mathrm{I}+\mathrm{I} \Leftrightarrow \mathrm{CH}_{3} \mathrm{I}+\mathrm{HI}\right)$ lebih cepat dari pembentukan intermediate (adsorpsi metana, $\mathrm{CH}_{4}+\mathrm{I} \Leftrightarrow \mathrm{CH}_{4} \mathrm{I}$ ). Energi aktivasi yang diperoleh sebesar 34,628 kJ/mol dan faktor pre-eksponensial 6,583 $\times 10^{6}$.
\end{abstract}

Kata kunci: karbon nanotube; reaksi dekomposisi metana; model kinetika mikro; katalis Ni-Cu-Al; tahap adsorpsi

\section{PENDAHULUAN}

Reaksi dekomposisi katalitik metana adalah salah satu alternatif produksi nanokarbon yang bernilai ekonomi tinggi dengan reaksi $\mathrm{CH}_{4} \rightarrow \mathrm{C}+2 \mathrm{H}_{2}$, $\Delta \mathrm{H}^{\mathrm{o}}{ }_{298 \mathrm{~K}}=75,6 \mathrm{~kJ} / \mathrm{mol}$. Metana dipilih sebagai reaktan karena metana merupakan hidrokarbon dengan perbandingan hidrogen/karbon yang paling tinggi dan bisa langsung didapat dari alam tanpa harus diolah terlebih dahulu sehingga mengurangi biaya produksi.

Reaksi dekomposisi katalitik metana tidak melibatkan reaksi lanjut untuk mengkonversi $\mathrm{CO}$ yaitu reaksi water gas shift $\left(\mathrm{CO}+\mathrm{H}_{2} \mathrm{O} \rightarrow \mathrm{CO}_{2}+\mathrm{H}_{2}\right)$ dan 
tidak menghasilkan $\mathrm{CO}_{2}$ (Martin-Gullon dkk., 2006) karena dekomposisi metana langsung mengkonversi unsur karbon menjadi material adi yaitu nano karbon (clean carbon). Karbon ini dapat digunakan sebagai produk komoditi atau disimpan (sequestration) untuk masa mendatang. Nanokarbon, khususnya Carbon Nano Tube (CNT) merupakan material yang menjadi obyek banyak penelitian di bidang teknologi nano karena CNT memiliki struktur yang unik, sifat mekanik dan sifat elektrik yang unggul, kekuatan yang tinggi sehingga berpeluang untuk aplikasi baru sebagai adsorben, katalis, material komposit, pelapis reaktor, pewarna, lubrikan, dan lain sebagainya yang memiliki nilai tambah yang tinggi (Purwanto dkk., 2005). Percobaan laboratorium dan studi kinetika reaksi intrinsik secara umum merupakan tahap awal menuju perkembangan reaktor industri.

Pengembangan teknologi produksi CNT melalui konversi katalitik hidrokarbon akan efisien dan efektif jika didasarkan pada pengetahuan mekanisme nukleasi dan pertumbuhan nanotube. Sebagian besar studi dilakukan untuk mempelajari kinetika dekomposisi metana untuk produksi hidrogen dalam rangka mengembangkan metode baru produksi hidrogen sebagai sumber efisien dari bahan bakar bersih (Zein dkk., 2004; Krestinin dkk., 2008; Philippe dkk., 2009; Hazra dkk., 2009). Riset difokuskan pada identifikasi produk utama dekomposisi dan estimasi energi aktivasi dekomposisi metana. Energi aktivasi dekomposisi metana menggunakan reaktor tubular tanpa katalis ditemukan $370 \mathrm{~kJ} / \mathrm{mol}$ untuk daerah suhu 1770-2270 K (Holmen dkk., 1976). Steinberg (1998) melaporkan energi aktivasi $131 \mathrm{~kJ} / \mathrm{mol}$ untuk dekomposisi metana pada daerah suhu 973-1173 K dan tekanan 28-56 atm yang nilainya lebih rendah dari harga dekomposisi metana tanpa katalis. Sharif Zein (2004) dengan menggunakan sistem unggun tetap dengan umpan campuran metana dan argon rasio 1:1 (tekanan parsial masing-masing 0,5 dan $100<v_{0}<450$ $\mathrm{mL} /$ menit) serta katalis $13 \% \mathrm{Ni} / \mathrm{TiO}_{2}$, melaporkan energi akivasi $60 \mathrm{~kJ} / \mathrm{mol}$ (valid untuk daerah $823<\mathrm{T}<1173 \mathrm{~K}$ dan laju orde satu). Nilai ini merupakan energi aktivasi terendah yang diteliti selama ini (Zein dkk., 2004).

Pada penelitian ini, kinetika dekomposisi katalitik metana menggunakan katalis $\mathrm{Ni}-\mathrm{Cu}-\mathrm{Al}$ untuk produksi karbon nanotube dilakukan dengan menguji data kinetika melalui model kinetika mikro yang diturunkan dari mekanisme reaksi permukaan katalis.

\section{METODE PENELITIAN}

Prekursor inti aktif, supporter, dan logam kedua, $\quad\left(\mathrm{Ni}\left(\mathrm{NO}_{3}\right)_{2} \cdot 6 \mathrm{H}_{2} \mathrm{O}, \quad \mathrm{Al}\left(\mathrm{NO}_{3}\right)_{3} .9 \mathrm{H}_{2} \mathrm{O}, \quad\right.$ dan $\mathrm{Cu}\left(\mathrm{NO}_{3}\right)_{2} \cdot 3 \mathrm{H}_{2} \mathrm{O}$ dengan perbandingan $\mathrm{Ni}: \mathrm{Cu}: \mathrm{Al}=$ 2:1:1 dipreparasi dengan metode kopresipitasi. Katalis dilarutkan ke dalam $500 \mathrm{~mL}$ deionized water hingga membentuk larutan garamnya pada suhu $50^{\circ} \mathrm{C}$. Selanjutnya larutan didinginkan hingga suhu kamar, kemudian di bawah pengadukan dengan magnetic stirrer larutan tersebut dititrasi dengan larutan sodium karbonat $\left(\mathrm{Na}_{2} \mathrm{CO}_{3}\right) 2 \mathrm{M}$ hingga $\mathrm{pH}$ larutan menjadi netral (atau $\mathrm{pH}=7$ ), larutan tersebut tetap diaduk selama kurang lebih 90 menit. Lalu larutan didiamkan dalam suhu dan tekanan ruang selama semalam. Endapan yang terbentuk disaring dengan buchner funnel. Wetcake yang didapat dicuci dengan deionized water dan aseton sebanyak kurang lebih lima kali.Wetcake dikeringkan dalam furnace atmosferik dengan suhu $120^{\circ} \mathrm{C}$ selama kurang lebih 5 jam. Katalis dikalsinasi dalam furnace atmosferik dengan suhu $250^{\circ} \mathrm{C}$ selama $1 \mathrm{jam}, 500^{\circ} \mathrm{C}$ selama 1 jam dan $800^{\circ} \mathrm{C}$ selama 1 jam. Karakterisasi katalis menggunakan XRF untuk melihat komposisi katalis, XRD untuk indentifikasi komponen dan kristalinitas.

Reaktor yang digunakan adalah reaktor unggun tetap yang terbuat dari tabung kaca quartz, dengan diameter $16 \mathrm{~mm}$ untuk bagian atas dan $12 \mathrm{~mm}$ untuk bagian bawah dengan panjang $50 \mathrm{~cm}$. Percobaan untuk pengumpulan data kinetik dilakukan pada kondisi operasi yang memenuhi syarat, yaitu laju reaksi yang tidak dipengaruhi oleh limitasi difusi eksternal, tahanan antar fasa dan laju difusi internal. Di samping itu, perlu pengaturan waktu tinggal (W/F) dan dibuat konstan pada masing-masing suhu agar konversi yang diperoleh cukup rendah $(<15 \%)$, dengan demikian pengolahan datanya dapat didekati dengan teknik perhitungan reaktor diferensial dan efek reaksi balik dapat diabaikan. Kondisi ini dapat dicapai dengan menggunakan diameter katalis, laju alir, dan waktu tinggal umpan yang sesuai. Selain itu reaktor mengikuti pola aliran plug dan kondisi isotermal.

Percobaan kinetika dekomposisi metana dilakukan sebagai berikut: 0,04 gram katalis dicampur dengan 0,0728 gram kuarsa yang mempunyai diameter yang sama untuk meminimalisasi jatuh tekan dan memperoleh temperatur yang seragam di seluruh unggun. Campuran ini dimasukkan ke dalam reaktor. Katalis direduksi selama 1 jam pada suhu $700 \mathrm{~K}$. Kemudian temperatur reaktor diatur untuk memulai reaksi. Laju alir metana adalah $160 \mathrm{~mL} /$ menit. Semua reaksi terjadi pada tekanan atmosfir, komposisi keluar gas diukur dengan gas kromatografi. Argon digunakan sebagai gas pembawa (carrier gas). Reaksi dilakukan selama 1 jam dan laju pembentukan karbon dihitung menggunakan pendekatan neraca karbon terhadap waktu.

\section{Data Kinetika}

Pengumpulan data kinetika dilakukan pada temperatur reaksi $650-750^{\circ} \mathrm{C}$ dengan kenaikan $10^{\circ} \mathrm{C}$, rasio berat katalis terhadap laju alir massa metana $\left(\mathrm{W} / \mathrm{F}_{\mathrm{A} 0}\right) 2,25 \times 10^{-4}$ dan menggunakan katalis berukuran di bawah $0,25 \mathrm{~mm}$ dan laju alir $160 \mathrm{~mL} /$ menit. Menurut Rase (1987), Froment dan Bischoff (1990) dan Geankoplis (2000) ada kriteria lain reaktor packed bed untuk meyakinkan kondisi aliran dalam reaktor mendekati aliran plug agar memperoleh operasi reaktor isotermal, mengeliminasi pencampuran balik (back mixing) dan meminimalisasi channeling. Kriteria pertama adalah memilih rasio tinggi unggun 
(bed length) terhadap diameter partikel ( $L / d p)$. Untuk sistem gas padat, tinggi unggun katalis $(L)$ minimal harus 50 kali lebih besar dari diameter partikel $(L / d p>50)$. Kriteria kedua adalah diameter reaktor $(D)$ minimal harus 10 kali diameter partikel katalis $\left(d_{p}\right)$ $\left(D / d_{p}>10\right)$. Dalam penelitian ini, $L / d p$ sebesar 51 dan $D / d p$ sebesar 96. Nilai-nilai ini digunakan untuk semua pengambilan data kinetika agar perilaku aliran dalam reaktor adalah plug.

\section{HASIL DAN PEMBAHASAN}

\section{Preparasi dan Karakterisasi Katalis}

Prekursor yang digunakan untuk pembuatan katalis adalah $\mathrm{Ni}\left(\mathrm{NO}_{3}\right)_{2} \cdot 6 \mathrm{H}_{2} \mathrm{O}, \mathrm{Cu}\left(\mathrm{NO}_{3}\right)_{2} \cdot 3 \mathrm{H}_{2} \mathrm{O}$, dan $\mathrm{Al}\left(\mathrm{NO}_{3}\right)_{3} .9 \mathrm{H}_{2} \mathrm{O}$, serta $\mathrm{Na}_{2} \mathrm{CO}_{3}$ sebagai presipitan. Dari hasil proses pencampuran prekursor dan pengendapan dengan penambahan presipitan diperoleh endapan berwarna putih kehijauan.

Kalsinasi $\mathrm{Ni}_{4} \mathrm{Cu}_{2} \mathrm{Al}_{2}(\mathrm{OH})_{16}\left(\mathrm{Al}_{2} \mathrm{O}_{4}\right)$ pada suhu $350^{\circ} \mathrm{C}$ dan $500^{\circ} \mathrm{C}$ umumnya merupakan proses pelepasan $\mathrm{H}_{2} \mathrm{O}$, sedangkan kalsinasi pada suhu $800^{\circ} \mathrm{C}$ merupakan tahap pemecahan senyawa mirip hydrotalcite menjadi beberapa senyawa oksida dan senyawa paduan dari logam yang ada.

Tahap paling menentukan dalam preparasi katalis dengan metode ko-presipitasi ini adalah pembentukan endapan. Kuantitas $\mathrm{Cu}$, Ni dan $\mathrm{Al}$ sangat ditentukan oleh jumlah endapan yang terbentuk dari masing-masing spesies material endapan yang mungkin terjadi, karena proses pengendapan bersifat balik (reversible) hingga terjadi kesetimbangan. Karena di larutan terdapat banyak spesies ion (anion dan kation), maka terjadi kompetisi dalam pembentukan endapan hingga terjadi kondisi kesetimbangan. Keberadaan ion (anion maupun kation) dari luar akan mengubah kondisi kesetimbangan yang telah terjadi menuju kesetimbangan barunya.

Pada kasus ini, endapan yang muncul adalah $\mathrm{Ni}(\mathrm{OH})_{2}, \mathrm{Cu}(\mathrm{OH})_{2}$, dan $\left[\mathrm{Cu}\left(\mathrm{H}_{2} \mathrm{O}\right)_{6}\right] \mathrm{Al}_{2} \mathrm{O}_{4}$ seperti pada Gambar 1.

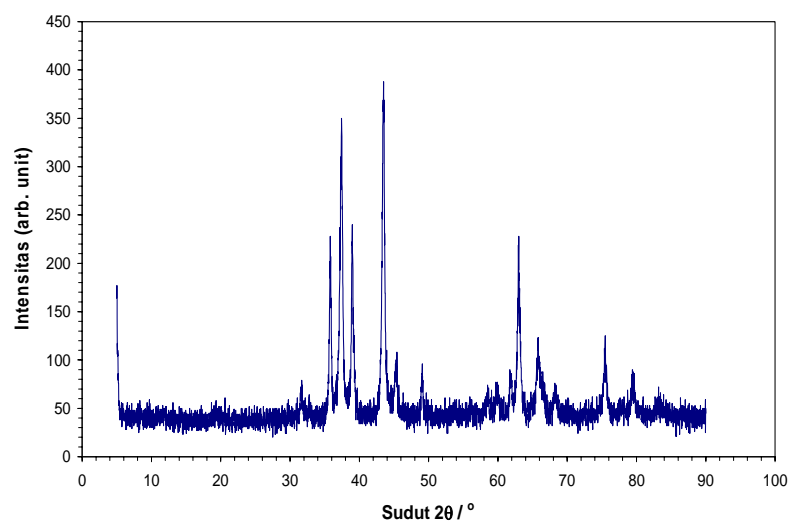

Gambar 1. Hasil karakterisasi XRD

Atom $\mathrm{Cu}$ ada dalam 2 jenis endapan, sedangkan atom $\mathrm{Ni}$ dan $\mathrm{Al}$ bersumber dari satu jenis endapan saja, sehingga apabila proses pengendapan keempat jenis endapan tidak berjalan secara optimal maka ketidaksesuaian perbandingan mol ketiga logam tersebut akan menjadi besar. Pada penelitian ini tidak teridentifikasi fasa kristalin $\mathrm{Cu}_{\mathrm{x}} \mathrm{Ni}_{\mathrm{y}} \mathrm{Al}_{2} \mathrm{O}_{4}$ dan alloy Ni$\mathrm{Cu}$.

Karakterisasi XRF (X-Ray Fluorescence) untuk mengetahui komposisi fraksi $\mathrm{Ni}: \mathrm{Cu}: \mathrm{Al}$, menggunakan JEOL Element Analyzer JSX-3211. Data yang diperoleh berupa unsur yang terdeteksi, persen berat, persen atom $/ \mathrm{mol}$, rasio-K, integral int, serta deviasi standar. Hasil karakterisasi XRF menunjukkan nilai rasio $\mathrm{Ni}, \mathrm{Cu}$, dan $\mathrm{Al}$ berturut-turut adalah 2:1:1,32. Unsur kalsium dan besi yang terdeteksi memiliki fraksi berat yang sangat kecil sehingga dapat dianggap sebagai pengotor.

\section{Kinetika Reaksi}

Operasi reaktor diferensial dicapai bila konversi pada unggun katalis sangat kecil sehingga perubahan komposisi tidak mempengaruhi laju pembentukan karbon. Untuk memastikan operasi isobarik, diameter partikel harus dipilih dengan hatihati.

Berdasarkan hasil percobaan pendahuluan, diperoleh daerah kinetika yang didapat adalah sebagai berikut :

- Diameter partikel : : 0,125-0,25 mm

- Laju alir umpan total : $160 \mathrm{~mL} / \mathrm{menit}$

- Tekanan reaksi (P) : 1 Atmosfir

- Suhu reaksi $\left({ }^{\circ} \mathrm{C}\right) \quad: 650-750^{\circ} \mathrm{C}$

- Berat katalis : 0,04 gram

Studi kinetika mikro diawali dengan memformulasikan mekanisme reaksi berdasarkan reaksi-reaksi elementer yang terjadi pada permukaan katalis. Dari mekanisme reaksi elementer yang telah dirumuskan dan dengan asumsi-asumsi yang relevan dapat diformulasikan persamaan laju reaksi katalitiknya. Persamaan laju reaksi yang diperoleh disebut persamaan kinetika mikro. Untuk menentukan parameter-parameter kinetik yang ada, persamaan kinetika mikro tersebut kemudian diuji dengan data percobaan menggunakan metode regresi tak linier.

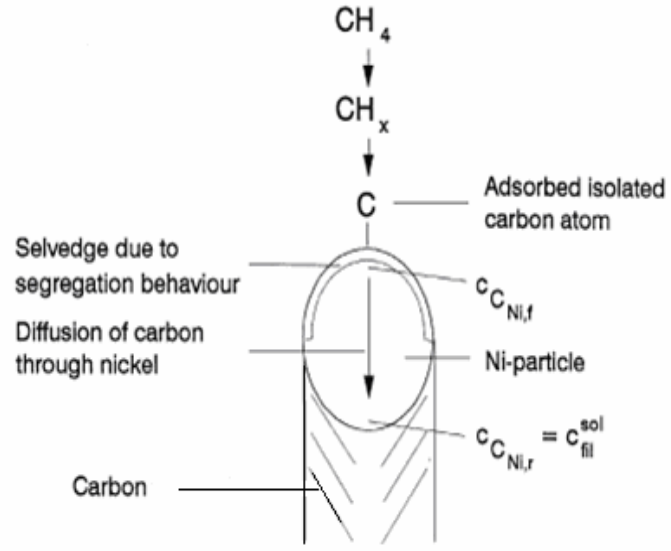

Gambar 2. Detil mekanisme pembentukan karbon filamen atau karbon nanotubes melalui perengkahan metana (Snoeck dkk., 1997, KOC dkk., 2009) 
Pemodelan mempertimbangkan dua aspek yaitu reaksi permukaan dan pembentukan nano karbon, dalam hal ini karbon filamen seperti yang dilakukan Snoeck (1997) dengan skema perengkahan metana seperti yang terlihat pada Gambar 2.

Produk utama reaksi, karbon yang teradsorpsi, tidak terdesorbsi masuk fase gas tetapi terlarut dalam nikel, berdifusi melaluinya dan mengendap pada sisi di dekat kristalit nikel dengan pembentukan karbon nanotube/karbon filamen (Snoeck dkk., 1997; KOC dkk., 2009).

Penyusunan persamaan lajunya bertumpu pada mekanisme reaksi yang terjadi. Mekanisme reaksi yang dilakukan dalam studi ini mengikuti mekanisme yang diusulkan oleh Snoeck dkk. (1997) dengan tahap sebagai berikut di mana I adalah inti aktif katalis :

Adsorpsi:

1. $\mathrm{CH}_{4}+\mathrm{I} \Leftrightarrow \mathrm{CH}_{4} \mathrm{I}$

Reaksi Permukaan:

2. $\mathrm{CH}_{4} \mathrm{I}+\mathrm{I} \Leftrightarrow \mathrm{CH}_{3} \mathrm{I}+\mathrm{HI}$

3. $\mathrm{CH}_{3} \mathrm{I}+\mathrm{I} \Leftrightarrow \mathrm{CH}_{2} \mathrm{I}+\mathrm{HI}$

4. $\mathrm{CH}_{2} \mathrm{I}+\mathrm{I} \Leftrightarrow \mathrm{CHI}+\mathrm{HI}$

5. $\mathrm{CHI}+\mathrm{I} \Leftrightarrow \mathrm{CI}+\mathrm{HI}$

Desorpsi:

6. $2 \mathrm{HI} \Leftrightarrow \mathrm{H}_{2}+2 \mathrm{I}$

7. $\mathrm{CI} \Leftrightarrow \mathrm{C}_{\mathrm{Ni}, \mathrm{f}}+\mathrm{I}$
Penurunan persamaan laju reaksi berkatalis heterogen ini didasarkan pada adsorpsi isoterm Langmuir-Hinshelwood-Hougen-Watson (LHHW) karena metode ini bentuknya sederhana dan hasilnya cukup memadai (sesuai dengan hasil percobaan). Isoterm ini didasarkan pada asumsi keaktifan inti aktif katalis seragam dan adsorpsi yang terjadi adalah reaksi reversibel elementer antara adsorbat dengan inti aktif katalis. Konsentrasi spesies pada fasa gas dapat digantikan oleh tekanan parsial masing-masing oleh isoterm Langmuir, sehingga: $\left[\mathrm{CH}_{4}\right]=\mathrm{P}_{\mathrm{CH}_{4}}$ dan $\left[\mathrm{H}_{2}\right]=\mathrm{P}_{\mathrm{H}_{2}}$.

Konsentrasi permukaan karbon tidak dapat dihubungkan secara langsung oleh tekanan parsial fase gas (Snoeck dkk., 1997), sehingga diusulkan bahwa kesetimbangan segregasi (pemisahan) digambarkan dengan cara yang sama seperti adsorpsi gas dan kompetisi yang terjadi di antara kedua proses $\mathrm{CI} \Leftrightarrow$ $\mathrm{C}_{\mathrm{Ni}, \mathrm{f}}+\mathrm{I}$

$$
\left.\mathrm{K}_{\mathrm{C}}=\frac{[\mathrm{CI}]}{\left.\left[\mathrm{C}_{\mathrm{Ni}, \mathrm{f}}\right] \mathrm{I}\right]} \text { maka }[\mathrm{CI}]=\mathrm{K}_{\mathrm{C}} \mid \mathrm{C}_{\mathrm{Ni}, \mathrm{f}} \llbracket \mathrm{I}\right]
$$

Tabel 1. Ringkasan model persamaan laju reaksi dekomposisi metana

\begin{tabular}{|c|c|c|}
\hline $\begin{array}{c}\text { Tahap Pembatas } \\
\text { Laju Reaksi }\end{array}$ & Model Persamaan Laju Reaksi & Persamaan \\
\hline $\begin{array}{c}\text { MODEL 1 } \\
\text { Adsorpsi Metana } \\
\text { sebagai TPL }\end{array}$ & $\mathrm{r}_{\mathrm{C}, \mathrm{M}}=\mathrm{r}_{\mathrm{CH}_{4}}=\frac{\left(\mathrm{k}_{\mathrm{M}}^{+} \cdot \mathrm{p}_{\mathrm{CH}_{4}}-\frac{\mathrm{k}_{\mathrm{M}}^{-1}}{\mathrm{~K}_{\mathrm{r}}^{\prime \prime} \cdot \mathrm{K}_{2}} \cdot \mathrm{p}_{\mathrm{H}_{2}}^{2}\right)}{\left(1+\frac{1}{\mathrm{~K}_{\mathrm{r}}^{\prime \prime}} \cdot \mathrm{p}_{\mathrm{H}_{2}}^{3 / 2}+\frac{1}{\mathrm{~K}_{\mathrm{r}}^{\prime} \cdot \mathrm{K}_{\mathrm{H}}^{1 / 2} \cdot \mathrm{K}_{2}} \cdot \mathrm{p}_{\mathrm{H}_{2}}^{2}\right)}$ & (2) \\
\hline $\begin{array}{c}\text { MODEL } 2 \\
\text { Reaksi permukaan } \\
\mathrm{CH}_{4} \mathrm{I} \text { menjadi } \mathrm{CH}_{3} \mathrm{I} \\
\text { dan } \mathrm{HI} \text { sebagai } \\
\text { TPL }\end{array}$ & $\mathrm{r}_{\mathrm{C}, \mathrm{M}}=\mathrm{r}_{\mathrm{CH}_{4} \mathrm{I}}=\frac{\mathrm{k}_{\mathrm{M}}^{+} \mathrm{K}_{\mathrm{CH}_{4}} \mathrm{p}_{\mathrm{CH}_{4}}-\frac{\mathrm{k}_{\mathrm{M}}^{-}}{\mathrm{K}_{\mathrm{r}}^{\prime \prime}} \mathrm{p}_{\mathrm{H}_{2}}^{2}}{\left(1+\frac{1}{\mathrm{~K}_{\mathrm{r}}^{\prime \prime}} \mathrm{p}_{\mathrm{H}_{2}}^{3 / 2}+\mathrm{K}_{\mathrm{CH}_{4}} \mathrm{p}_{\mathrm{CH}_{4}}\right)^{2}}$ & (3) \\
\hline $\begin{array}{c}\text { MODEL } 3 \\
\text { Reaksi Permukaan } \\
\mathrm{CH}_{3} \mathrm{I} \text { menjadi } \mathrm{CH}_{2} \mathrm{I} \\
\text { dan HI sebagai } \\
\text { TPL }\end{array}$ & $\mathrm{r}_{\mathrm{C}, \mathrm{M}}=\mathrm{r}_{\mathrm{CH}_{3} \mathrm{I}}=\frac{\mathrm{k}_{\mathrm{M}}^{+} \mathrm{K}_{\mathrm{CH}_{4}} \frac{\mathrm{K}_{2}}{\mathrm{~K}_{\mathrm{H}}^{1 / 2}} \frac{\mathrm{p}_{\mathrm{CH}_{4}}}{\mathrm{p}_{\mathrm{H}_{2}}^{1 / 2}}-\frac{\mathrm{k}_{\mathrm{M}}^{-}}{\mathrm{K}_{\mathrm{r}}^{\prime \prime}} \frac{1}{\mathrm{~K}_{\mathrm{H}}^{2} / \mathrm{K}_{3}} \mathrm{p}_{\mathrm{H}_{2}}^{3 / 2}}{\left(1+\frac{\mathrm{K}_{2} \mathrm{~K}_{\mathrm{CH}_{4}}}{\mathrm{~K}_{\mathrm{H}}^{1 / 2}} \frac{\mathrm{p}_{\mathrm{CH}_{4}}}{\mathrm{p}_{\mathrm{H}_{2}}^{1 / 2}}+\mathrm{K}_{\mathrm{CH}_{4}} \mathrm{p}_{\mathrm{CH}_{4}}\right)^{2}}$ & (4) \\
\hline $\begin{array}{c}\text { MODEL } 4 \\
\text { Reaksi Permukaan } \\
\mathrm{CH}_{2} \mathrm{I} \text { menjadi CHI } \\
\text { dan HI sebagai } \\
\text { TPL }\end{array}$ & $\mathrm{r}_{\mathrm{C}, \mathrm{M}}=\mathrm{r}_{\mathrm{CH}_{2} \mathrm{I}}=\frac{\left(\mathrm{k}_{\mathrm{M}}^{+} \mathrm{K}_{\mathrm{CH}_{4}} \frac{\mathrm{p}_{\mathrm{CH}_{4}}}{\mathrm{p}_{\mathrm{H}_{2}}}-\frac{\mathrm{k}_{\mathrm{M}}^{-}}{\mathrm{K}_{\mathrm{r}}^{\prime \prime}} \mathrm{p}_{\mathrm{H}_{2}}\right)}{\left(1+\frac{\mathrm{K}_{2} \mathrm{~K}_{\mathrm{CH}_{4}}}{\mathrm{~K}_{\mathrm{H}}^{1 / 2}} \frac{\mathrm{p}_{\mathrm{CH}_{4}}}{\mathrm{p}_{\mathrm{H}_{2}}^{1 / 2}}+\mathrm{K}_{\mathrm{CH}_{4}} \mathrm{P}_{\mathrm{CH}_{4}}\right)^{2}}$ & $(5)$ \\
\hline $\begin{array}{c}\text { MODEL } 5 \\
\text { Reaksi Permukaan } \\
\text { CHI menjadi CI } \\
\text { dan HI sebagai } \\
\text { TPL }\end{array}$ & $\mathrm{r}_{\mathrm{C}, \mathrm{M}}=\mathrm{r}_{\mathrm{CHI}}=\frac{\left(\mathrm{k}_{\mathrm{M}}^{+} \mathrm{K}_{\mathrm{CH}_{4}} \mathrm{~K}_{\mathrm{r}}^{\prime \prime} \frac{\mathrm{p}_{\mathrm{CH}_{4}}}{\mathrm{p}_{\mathrm{H}_{2}}^{3 / 2}}-\mathrm{k}_{\mathrm{M}}^{-} \mathrm{p}_{\mathrm{H}}^{1 / 2}\right)}{\left(1+\frac{\mathrm{K}_{2} \mathrm{~K}_{\mathrm{CH}_{4}}}{\mathrm{~K}_{\mathrm{H}}^{1 / 2}} \frac{\mathrm{p}_{\mathrm{CH}_{4}}}{\mathrm{p}_{\mathrm{H}_{2}}^{1 / 2}}+\mathrm{K}_{\mathrm{CH}_{4}} \mathrm{p}_{\mathrm{CH}_{4}}\right.}$ & (6) \\
\hline
\end{tabular}




\begin{tabular}{|c|c|c|}
\hline $\begin{array}{c}\text { MODEL } 6 \\
\text { Desorpsi Hidrogen } \\
\text { sebagai TPL }\end{array}$ & $\mathrm{r}_{\mathrm{C}, \mathrm{M}}=\mathrm{r}_{\mathrm{HI}}=\frac{\mathrm{k}_{\mathrm{M}}^{+} \mathrm{K}_{\mathrm{r}}^{1 / 2} \mathrm{~K}_{\mathrm{CH}_{4}}^{1 / 2} \mathrm{~K}_{\mathrm{H}}^{3 / 4} \mathrm{P}_{\mathrm{CH}_{4}}^{1 / 2}-\mathrm{k}_{\mathrm{M}}^{-} \mathrm{P}_{\mathrm{H}_{2}}}{\left(1+\frac{\mathrm{K}_{\mathrm{CH}_{4}}^{3 / 4} \mathrm{~K}_{2}^{2}}{\mathrm{~K}_{\mathrm{r}}^{\prime 4} \mathrm{~K}_{\mathrm{r}}^{\prime \prime 1 / 4} \mathrm{~K}_{\mathrm{H}}^{3 / 8}} \mathrm{P}_{\mathrm{CH}_{4}}^{3 / 4}+\mathrm{K}_{\mathrm{CH}_{4}} \mathrm{P}_{\mathrm{CH}_{4}}\right)^{2}}$ & (7) \\
\hline $\begin{array}{c}\text { MODEL } 7 \\
\text { Desorpsi Karbon } \\
\text { sebagai TPL }\end{array}$ & $\mathrm{r}_{\mathrm{C}, \mathrm{M}}=\mathrm{r}_{\mathrm{CI}}=\frac{\left(\frac{\mathrm{K}_{\mathrm{M}}^{+} \mathrm{K}_{\mathrm{CH}_{4}}}{\mathrm{~K}_{\mathrm{M}}^{-} \mathrm{K}_{\mathrm{H}}^{1 / 2}} \frac{\mathrm{K}_{\mathrm{r}}^{\prime \prime}}{\mathrm{K}_{\mathrm{C}}} \frac{\mathrm{P}_{\mathrm{CH}_{4}}}{\mathrm{P}_{\mathrm{H}_{2}}^{2}}-1\right)}{\left(1+\frac{\mathrm{K}_{2} \mathrm{~K}_{\mathrm{CH}_{4}}}{\mathrm{~K}_{\mathrm{H}}^{1 / 2}} \frac{\mathrm{P}_{\mathrm{CH}_{4}}}{\mathrm{P}_{\mathrm{H}_{2}}^{1 / 2}}+\frac{\mathrm{K}_{\mathrm{CH}_{4}}}{\mathrm{~K}_{\mathrm{H}}^{1 / 2}} \mathrm{~K}_{\mathrm{r}}^{\prime} \frac{\mathrm{P}_{\mathrm{CH}_{4}}}{\mathrm{P}_{\mathrm{H}_{2}}^{2}}+\mathrm{K}_{\mathrm{CH}_{4}} \mathrm{P}_{\mathrm{CH}_{4}}\right)^{2}}$ & (8) \\
\hline
\end{tabular}

Penurunan model berdasarkan asumsi bahwa setiap tahap reaksi pada mekanisme Snoeck tersebut untuk setiap kasus merupakan tahap pembatas laju (TPL). Dengan demikian diperoleh 7 model kinetika yang mertepresentasikan kinetika untuk tahap pembatas laju tertentu. Ketujuh model tersebut diringkas pada Tabel 1.

Untuk menentukan parameter-parameter kinetika yang ada, model-model tersebut kemudian dicocokkan dengan data kinetika yang diperoleh dari hasil eksperimental. Pencocokan model dilakukan secara regresi tak linear dengan menggunakan solver pada Microsoft Excel. Hasil pencocokan keseluruhan model dan parameter statistiknya adalah sebagai berikut pada Gambar 3.

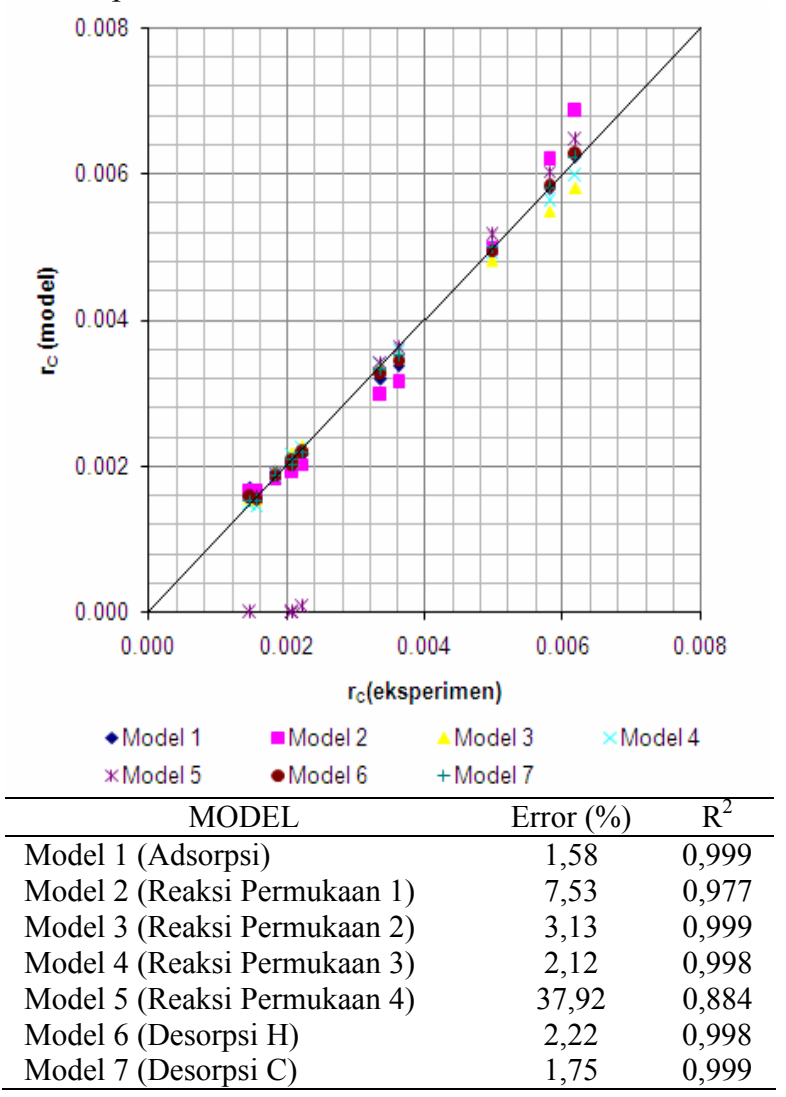

Gambar 3. Hasil pencocokan antara laju pembentukan karbon hasil eksperimen dengan laju pembentukan karbon pada setiap tahap/model dan tabel persentase kesalahan relatif berikut nilai $\mathrm{R}^{2}$
Hasil pencocokan laju percobaan dengan model yang mempunyai error di atas 5\% hanya Model 2 dan Model 5. Untuk memilih model yang tepat di antara ke-5 model lainnya dilakukan pengujian sebagai berikut :

a) Menguji ke-5 model tersebut untuk memperoleh energi aktifasi $\left(E_{a}\right)$ dan faktor pre-eksponensial (A) melalui persamaan Arrhenius $\mathrm{k}=\mathrm{A} \exp ^{-\mathrm{E}_{\mathrm{a}} / \mathrm{RT}}$

b) Melakukan analisis termodinamika terhadap parameter kinetika

Hasil pengujian untuk mendapatkan nilai energi aktivasi $\left(E_{a}\right)$ dan faktor pre-eksponensial dapat diperoleh dengan menggunakan persamaan Arrhenius, $\mathrm{k}=\mathrm{A} \exp ^{-\mathrm{E}_{\mathrm{a}} / \mathrm{RT}}$ dimana $\mathrm{A}$ adalah faktor preeksponensial, $\mathrm{T}$ adalah temperatur reaksi $(\mathrm{K}), \mathrm{E}_{\mathrm{a}}$ adalah energi aktivasi $(\mathrm{kJ} / \mathrm{mol})$, dan $\mathrm{R}$ adalah konstanta gas ideal (kJ/mol.atm). Nilai $E_{a}$ dan A dapat diperoleh dari hasil plot nilai ln $(\mathrm{k})$ dengan $(1 / \mathrm{T})$. Hasil pengujian (a) dari persamaan hasil plot antara $\mathrm{ln}$ (k) dan $(1 / \mathrm{T})$, dihasilkan nilai perhitungan energi aktivasi yang memungkinkan adalah pada tahap adsorpsi seperti pada Gambar 4 yang menunjukkan hasil plot antara $\ln (\mathrm{k})$ dan $(1 / \mathrm{T})$ dengan nilai $\mathrm{E}_{\mathrm{a}}$ sebesar $34,6278 \mathrm{~kJ} / \mathrm{mol}$ dan faktor pre-eksponensial $6.583 \times 10^{6}$.

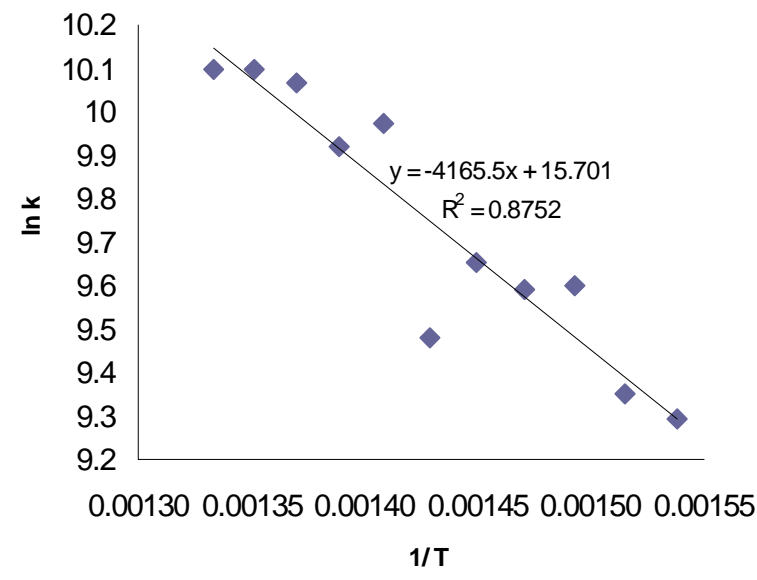

Gambar 4. Hubungan ln (k) dan 1/T

Pengujian (b) pada model LHHW, parameterparameter kinetika harus konsisten terhadap kriteriakriteria termodinamika (Xu dan Froment, 1989) : 
1. Energi aktivasi sesuai dengan persamaan $\overline{\mathrm{E}}>\mathrm{H}_{\mathrm{R}}$

2. $\Delta \mathrm{S}_{\mathrm{j}, \mathrm{a}}^{0}<0$ atau dengan $\exp \left(\Delta \mathrm{S}_{\mathrm{j}, \mathrm{a}}^{0} / \mathrm{R}\right)=\mathrm{A}\left(\mathrm{K}_{\mathrm{j}}\right)<1$

$\Delta \mathrm{S}_{\mathrm{j}, \mathrm{a}}^{0}=$ perubahan entropi komponen $\mathrm{j}$ dalam keadaan teradsorpsi, $\mathrm{kJ} /(\mathrm{kmol} . \mathrm{K})$

$\mathrm{A}\left(\mathrm{K}_{\mathrm{j}}\right)=$ faktor pre-eksponensial dari konstanta adsorpsi komponen $\mathrm{j}\left(\mathrm{K}_{\mathrm{j}}\right)$

Kriteria pertama tidak terpenuhi karena semua model memiliki energi aktivasi (Ea) yang lebih kecil dari entalpi reaksi, namun tahap adsorpsi memiliki nilai yang lebih masuk akal. Kriteria 2 yang memenuhi kriteria kedua hanya model adsorpsi karena nilai $\mathrm{A}\left(\mathrm{K}_{\mathrm{j}}\right)$ $=0,00135$ lebih kecil dari satu, permukaan 3 meskipun mempunyai nilai lebih kecil dari satu tetapi hal ini tidak mungkin karena bernilai negatif. Nilai konstanta laju dan koefisien kesetimbangan yang masuk akal hanya model 1 atau tahap adsorpsi dan model 7 atau tahap desorpsi $\mathrm{C}$ karena semua menghasilkan nilai positif

Menurut Snoeck dan Froment (1997) dan Reyyan KOC dkk. (2009), harga konstanta kesetimbangan termodinamika untuk estimasi konsentrasi karbon di lapisan segregasi saat reaksi

$$
\mathrm{CI} \rightarrow \mathrm{C}_{\mathrm{Ni}, \mathrm{f}}+\mathrm{I} \text { adalah } \mathrm{K}_{\mathrm{M}}=\left(-\frac{\Delta \mathrm{G}_{\mathrm{seg}}}{\mathrm{RT}}\right)
$$

dimana $\Delta \mathrm{G}_{\mathrm{seg}}=-45217-14,24 \mathrm{~T}(\mathrm{~kJ} / \mathrm{mol})$.

Melalui persamaan ini diperoleh konstanta kesetimbangan adalah 7,302 kJ/mol (Reyyan KOC dkk., 2009). Dari model persamaan yang ada, nilai $K_{M}$ yang mendekati nilai $\mathrm{K}_{\mathrm{M}}$ dekomposisi metana 7,302 $\mathrm{J} / \mathrm{mol}$ adalah model 1 atau tahap adsorpsi yaitu $4,36964 \mathrm{~kJ} / \mathrm{mol}$.

Berdasarkan hasil pengujian (a) dan (b) maka tahap adsorpsi atau model 1 menjadi tahap pembatas laju (TPL). Oleh karena itu model yang paling baik dalam merepresentasikan data dari hasil eksperimen ini adalah model kinetika dari persamaan (2) atau model 1 dengan persamaan laju :

$$
\begin{aligned}
\mathrm{r}_{\mathrm{C}, \mathrm{M}}=\mathrm{r}_{\mathrm{CH}_{4}} & =\left(6,583 \times 10^{6} \mathrm{e}^{-34,6278 / \mathrm{RT}}\right) \\
& \left.\mathrm{x} \frac{0,002933 * \mathrm{P}_{\mathrm{CH}_{4}}-\mathrm{P}_{\mathrm{H}_{2}}^{2}}{\left(1+0,056322 \mathrm{P}_{\mathrm{H}_{2}}^{3 / 2}+0,149087 \mathrm{P}_{\mathrm{H}_{2}}^{2}\right.}\right)
\end{aligned}
$$

Nilai energi aktivasi $34,6278 \mathrm{~kJ} / \mathrm{mol}$ dan faktor pre-eksponensial $6,583 \times 10^{6}$. Nilai energi aktivasi yang diperoleh ini dapat berlaku untuk rentang suhu percobaan yakni $650-750^{\circ} \mathrm{C}(923-1023 \mathrm{~K})$.

Persamaan laju di atas dapat dihubungkan sebagai fungsi temperatur melalui persamaan Arhenius untuk konstanta laju dan persamaan Van Hoff untuk konstanta kesetimbangan dengan hasil :

$$
\mathrm{r}_{\mathrm{C}, \mathrm{M}}=\mathrm{r}_{\mathrm{CH}_{4}}=\frac{\left(\mathrm{k}_{\mathrm{M}}^{+} \mathrm{P}_{\mathrm{CH}_{4}}-\frac{\mathrm{k}_{\mathrm{M}}^{-1}}{\mathrm{~K}_{\mathrm{r}}^{\prime} \mathrm{K}_{2}} \mathrm{P}_{\mathrm{H}_{2}}^{2}\right)}{\left(1+\frac{1}{\mathrm{~K}_{\mathrm{r}}^{\prime \prime}} \mathrm{P}_{\mathrm{H}_{2}}^{3 / 2}+\frac{1}{\mathrm{~K}_{\mathrm{H}}^{1 / 2} \mathrm{~K}_{2}} \frac{1}{\mathrm{~K}_{\mathrm{r}}^{\prime}} \mathrm{P}_{\mathrm{H}_{2}}^{2}\right)}
$$

dimana :

$$
\begin{aligned}
& \mathrm{k}_{\mathrm{M}}^{+}=5,533 \exp (-47531 / \mathrm{RT}) \\
& \mathrm{k}_{\mathrm{M}}^{-}=1,856 \exp (-22774,4 / \mathrm{RT}) \\
& \mathrm{K}_{\mathrm{r}}^{\prime}=\exp (101,9 / \mathrm{R}) * \exp (-94018,3 / \mathrm{RT}) \\
& \mathrm{K}_{\mathrm{r}}^{\prime \prime}=\exp (121,7 / \mathrm{R}) * \exp (-113233,5 / \mathrm{RT}) \\
& \mathrm{K}_{\mathrm{H}}=\exp (127,2 / \mathrm{R}) * \exp (-117360 / \mathrm{RT}) \\
& \mathrm{K}_{2}=\exp (77,67 / \mathrm{R}) * \exp (-71691,6 / \mathrm{RT})
\end{aligned}
$$

Nilai energi aktivasi yang diperoleh pada penelitian ini memperoleh hasil yang lebih rendah dibandingkan Zein dkk. (2004) yang sampai saat ini memperoleh energi aktivasi paling rendah dibandingkan peneliti lain yaitu $60 \mathrm{~kJ} / \mathrm{mol}$ (valid untuk daerah $823<\mathrm{T}<1173 \mathrm{~K}$ dan laju orde satu). Tahap pembatas laju untuk kinetika yang dilakukan juga tahap adsorpsi dengan analisa data menggunakan metode integral. Menurutnya reaksi permukaan kurang disukai sebagai pengontrol laju karena reaksi terjadi pada temperatur yang relatif tinggi $\left(>650^{\circ} \mathrm{C}\right.$ ).

Asai, Kuota, 2008 menemukan tahap pembatas laju pada penelitiannya menggunakan TGA (Thermo Gravimetric Apparatus) untuk katalis nikel yang disangga oleh $\mathrm{Al}_{2} \mathrm{O}_{3}$ adalah adsorpsi. Suhu yang dilakukan di atas $680^{\circ} \mathrm{C}$ dengan harga energi aktivasi sebesar 75,2 kJ/mol. Menurut Asai, mekanisme dissolution-precipitation secara umum diterima sebagai mekanisme pertumbuhan CNT pada katalis Ni selama dekomposisi metana (Nagayasu, 2006) yaitu metana yang teradsorpsi pada permukaan nikel akan terdekomposisi menjadi karbon dan hidrogen. Karbon yang terdeposit larut ke dalam sebagian besar partikel nikel, berdifusi melalui partikel logam, dan diendapkan sebagai CNT pada sisi belakang. Daya dorong bagi difusi karbon melalui partikel nikel dapat berupa gradien konsentrasi karbon atau gradien suhu pada partikel nikel.

\section{KESIMPULAN}

Hasil percobaan pendahuluan kinetika menunjukkan bahwa pengaruh difusi eksternal dapat diabaikan pada laju alir di atas $150 \mathrm{~mL} /$ menit. Difusi internal dapat diabaikan menggunakan diameter katalis di bawah $0,25 \mathrm{~mm}$ dengan berat katalis 0,04 gram pada waktu kontak $2,5 \times 10^{-4}$ gram. menit $/ \mathrm{mL}$.

Hasil pencocokan antara laju pembentukan karbon hasil eksperimen dengan laju pembentukan karbon pada setiap tahap/model, ditemukan lima model yang memiliki hubungan yang baik antara laju pembentukan karbon percobaan dan perhitungan sehingga perlu dilakukan pengujian melalui nilai energi aktivasi, faktor pre-eksponensial dan hubungan termodinamika dengan parameter kinetik.

Analisis persamaan laju menunjukkan bahwa tahap pembatas laju adalah tahap adsorpsi dengan energi aktivasi yang diperoleh sebesar $34,628 \mathrm{~kJ} / \mathrm{mol}$ dan faktor pre-eksponensial $6,583 \times 10^{6}$.

\section{UCAPAN TERIMA KASIH}

Penulis mengucapkan terima kasih kepada Direktorat Jenderal Pendidikan Tinggi Departemen 
Pendidikan Nasional-Republik Indonesia dan Direktorat Penelitian dan Pengabdian Masyarakat Universitas Indonesia. Penulis juga ingin mengucapkan terima kasih pada Anindya Adi Wardhana untuk kerjasamanya dalam pengambilan data.

\section{DAFTAR NOTASI}

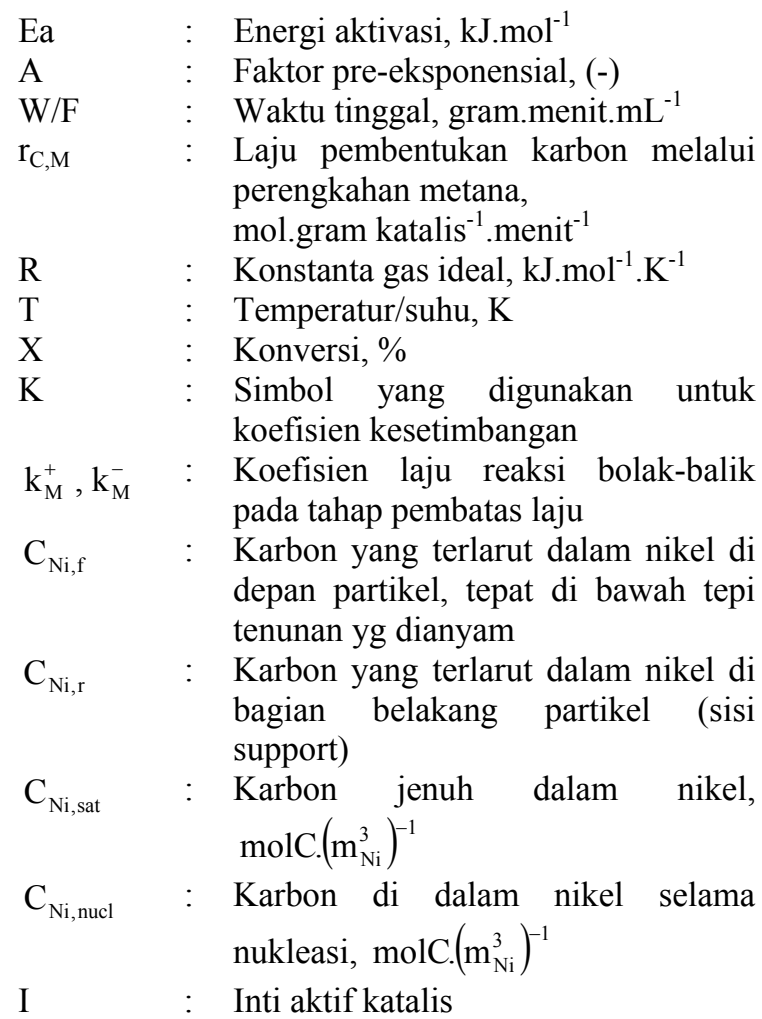

\section{DAFTAR PUSTAKA}

Hazra, M., Croiset, E., Hudgins, R. R., Silveston, P. L., and Elkamel, A., (2009), Experimental Investigation of the Catalytic Cracking of Methane Over A Supported Ni Catalyst, The Canadian Journal Of Chemical Engineering, 87, pp. 99-105.

Holmen, A., Rockstad, O. A., and Solbaklen, A., (1976), A. High-Temperature Pyrolysis of
Hydrocarbons. 1. Methane to Acetylene, Ind. Eng. Chem. Process Des. Dev., 15, pp. 439.

Koc, R., Alper, E. G., Croiset, E., and Elkamel, A., (2009), Partial Regeneration of Ni-Based Catalysts for Hydrogen Production Via Methane Cracking Part II: Modeling and Optimization, Turk J Nchem, 33, pp. 825-841.

Krestinin, A. V., Raevskii, A. V., and Kislov, M. B., (2008), Growth Rate of Carbon Filaments During Methane Pyrolysis on An Iron Catalyst with Analysis Using A Kinetic-Thermodynamic Approach, Carbon, 46, pp. 1450-1463.

Martin-Gullon, I., Vera, J., Conesa, J. A., González, J. L., and Merino, C., (2006), Differences Between Carbon Nanofibers Produced Using $\mathrm{Fe}$ and $\mathrm{Ni}$ Catalysts in A Floating Catalyst Reactor, Carbon, 44, pp. $1572-1580$.

Philippe, R., Serp, P., Kalck, P., Bordère, S., Plee, D., Gaillard, P., Bernard, D., and Caussat, B., (2009), Kinetic Modeling Study of Carbon Nanotubes Synthesis by Fluidized Bed Chemical Vapor Deposition, Aiche Journal, 55, pp. 465-474.

Purwanto, W. W., Saputra, E., and Song, L., (2005), Utilization of Very Small Field of Natural Gas by Methane Catalytic Decomposition, Effect of Nickel Catalyst Diameter and Acidity on Nanocarbon and Hydrogen Quality and Methane Activation. In: The International Energy Conference, Scncer 7th Asean Science And Technology Weeks, Jakarta.

Snoeck, J. W., Froment, G. F., and Fowles, M., (1997), Kinetic Study of the Carbon Filament Formation by Methane Cracking on A Nickel Catalyst, Journal Of Catalysis, 169, pp. 250-262.

Zein, S. H. S., Mohamed, A. R., and Sai, P. S. T., (2004), Kinetic Studies on Catalytic Decomposition of Methane to Hydrogen and Carbon over $\mathrm{Ni} / \mathrm{TiO}_{2}$ Catalyst, Ind. Eng. Chem. Res., 43, pp. 4864-4870. 